\title{
Quantitative Descriptive Analysis and Acceptance Testing of Yogurt with no Added Sugar
}

\author{
Claudia Regina S. Amaral ${ }^{1}$, Priscila Becker Siqueira ${ }^{2}$, Luciane Yuri Yoshiara ${ }^{2}$, Edgar Nascimento ${ }^{1}$, Rozilaine A. \\ P. Gomes de Faria ${ }^{1} \&$ Nagela Farias M. Picanço ${ }^{1}$ \\ ${ }^{1}$ Federal Institute of Education, Science and Technology of Mato Grosso, Cuiabá Bela Vista, Campus, CEP, \\ 78050-560, Cuiabá, MT, Brazil \\ ${ }^{2}$ Faculty of Nutrition, Federal University of Mato Grosso, Cuiabá, Mato Grosso, Brazil \\ Correspondence: Rozilaine A. P. Gomes de Faria, Departamento de Pesquisa, Ensino e Extensão, Instituto Federal \\ de Educação, Ciência e Tecnologia de Mato Grosso - IFMT, Avenida Juliano Costa Marques, s/n, Bairro Bela \\ Vista, Cuiabá, Brazil. Tel: 55-659-253-0207. E-mail: rozilaine.faria@blv.ifmt.edu.br
}

Received: December 22, 2019

Accepted: February 6, $2020 \quad$ Online Published: February 18, 2020

doi:10.5539/jfr.v9n2p7

URL: https://doi.org/10.5539/jfr.v9n2p7

\begin{abstract}
This study aimed to evaluate the effect of sucralose added in Greek Yogurt flavored with araticum (Annona crassiflora) and mangaba (Hancornia speciosa) through sensory characterization. The Greek yogurt was prepared with skimmed milk, inoculated starter cultures, filtered and it was supplemented with the appropriate amount of sucralose, added sweetened and pasteurized fruit pulp (araticum or mangaba). The total phenolic compounds and texture were performed and sensory analyses were carried out by Quantitative descriptive analysis (QDA) and acceptance test in storage for 7 and 28 days. The QDA results showed that the main attributes were color, lightness, creaminess, presence of particles, fullness, and aroma. Eighty percent and 85\% of the panelists were said they would buy the araticum Greek yogurt and the mangaba Greek yogurt after 7 days of storage, respectively. Additionally, $71 \%$ and $77 \%$ were said they would buy the araticum Greek yogurt and the mangaba Greek yogurt after storage for 28 days at $4^{\circ} \mathrm{C}$, respectively. The sensory profile and acceptance test results of the Greek yogurts developed indicated no perceptions caused by adding sucralose to the yogurt after storage for different times. The highest concentration of phenolic compounds in the araticum Greek yogurt was perceived by the panelists in aroma and flavor attributes. Changing sucrose to sucralose was not imperceptible under the storage and consumption conditions.
\end{abstract}

Keywords: araticum, Annona crassiflora, dairy product, greek yogurt, Hancornia speciosa, mangaba, sucralose

\section{Introduction}

The growing awareness of the risks for developing diseases such as obesity and diabetes, which are associated with the consumption of diets rich in fats and sugars, has generated discussions regarding the popularity of Greek yogurt, propelling the demand for versions with a reduction, elimination, and or substitution of these components (Jaoude et al., 2010). Substituting sucrose with a sweetener conditioned to meet the sensory-characteristic requirements of the products prepared, which must be indistinguishable to products elaborated with sucrose, is the most important condition for guaranteeing the acceptability of the product. Methods such as magnitude estimation and graphical representation of the data using Steven's power function are used to estimate the sugar content (Cardoso \& Bolini, 2007; Moraes \& Bolini, 2010; Souza et al., 2011; De Souza et al., 2013; Esmerino et al., 2013).

The sensory quality is one of the fundamental aspects most intimately associated with the perceived quality by the consumer and, consequently, with the product choice (Dutcosky, 2013). The sensory analysis has been used by food industries to ensure the acceptability of the new product in the consumer market (Carbonell-Barrachina, 2019). Quantitative Descriptive Analysis (QDA) is a sophisticated method capable of offering a complete sensory description of the product, i.e., it can be used to identify the main differences in food quality and intensity between products. The results can reveal correlations between the ingredients or process variables and the sensory attributes (Stone \& Sidel, 2004). In turn, the acceptance test is the main quantitative affective test used to evaluate the responses of a large number of consumers to a series of questions, aimed at identifying the overall acceptance level of a product, determining sensory factors affecting consumer preferences, or measuring 
specific responses to different sensory attributes of a product (Dutcosky, 2013). The combination of these methodologies is important, not only for evaluating the sensory functionality and quality of the product but also for understanding how these qualities are perceived and valued by consumers.

Sucralose is the only commercial sweetener derived from sucrose with high sweetening power, with quickly perceived and long-lasting sweetness concerning sucrose, with no residual bitter or metallic taste, it was selected as the sweetener for the study and the sweetening power of sucralose was studied previously by different authors (Souza et al., 2011; Morais, Morais, Cruz, \& Bolini, 2014; Reis, Minim, Dias, Chaves, \& Minim, 2009; Rodrigues, Paixão, Cruz, \& Bolini, 2015).

Conventional yogurt has always been known to consumers as a liquid drink, thinner in texture and easy to intake and for this reason, appreciated by different age groups. However, recently the incorporation in the yogurt by milk powder or material rich in protein has provided the development of a more concentrated milk product and the change in the production process can interfere with the physicochemical properties and sensory acceptability by the consumer (Jørgensen et al., 2019).

Concentrated yogurt is a semisolid product that is derived from yogurt and is characterized by cream or white color, smooth texture, good spreading, and a slightly acidic flavor (Nsabimana, Jiang, \& Kossah, 2005). The production process used for concentrated yogurt differs from that of traditional yogurt by the dewheying process in fabric bags at a small scale or centrifugation at the industrial scale. Concentrated yogurt is produced in many countries under different names such as Labneh (Middle east), Skyr (Iceland), Shrikhand (India), and Greek Yogurt (Greece and other countries) (Ramos, Gajo, Pinto, Abreu, \& Pinheiro, 2009). Cow's milk, sheep's milk, and goat's milk can be used to produce Greek yogurt, although cow's milk and, to a lesser extent, goat's milk are most commonly used (Tamime \& Robinson, 2007).

The fruits of the Cerrado have been highlighted due to the flavor and aroma and represent a source of good fiber and antioxidants (Morais et al., 2017) and their use in the development of new products represents an important alternative. Furthermore, it contributes to the large consumption of fruits and milk, provides an entirely new experience in terms of flavor, and promotes sustainable extractivism, thereby strengthening existing markets and intensifying the conquest of new markets.

In this study, we aimed to develop and evaluate formulations of Greek yogurt flavored with araticum and mangaba, and to characterize the sensory profile of the products and the effect of their characteristics as a function of their time in storage.

\section{Method}

To produce Greek yogurt flavored with fruits from the Cerrado, directly inoculated mixtures of ultra-high temperature (UHT) milk, skim powder milk (Piracanjuba ${ }^{\circledR}$ ), and Sucralose sweetener (Splenda, Johnson) with DELVO ${ }^{\circ} Y O G$ FVV $21 \frac{1}{2} \mathrm{U}$ lyophilized concentrated dairy culture containing Lactobacillus delbrueckii subspecies bulgaricus and Streptococcus thermophilus (Globalfood, Advanced Food Technology). Frozen araticum and mangaba pulps were provided by Frutos do Brasil Ltda. ME, a Frozen Edibles company, located in Goiânia, Goiás. The pulps were transported in isothermal boxes on dry ice to the Federal Institute of Education, Science and Technology of Mato Grosso (Instituto Federal de Educação, Ciência e Tecnologia de Mato Grosso) Cuiabá Campus, Bela Vista, Cuiabá - MT, where they were stored at $-18^{\circ} \mathrm{C}$ until the time of analysis.

The araticum and mangaba fruit pulps were heated to $75^{\circ} \mathrm{C}$ for $30 \mathrm{~min}$ in water bath and subsequently cooled in an ice bath, followed by the addition of sucralose sweetener equivalent to $50 \%$ sucrose, based on the claim that the sweetness power of sucralose is 600 times that of sucrose (Goldsmith and Merkel, 2001). Then, the fruit pulps were packaged in polyethylene containers with a capacity of $250 \mathrm{~g}$, were provided by Cia das Embalagens, Mato Grosso, Brazil, followed by storage in a BOD (biochemical oxygen demand) model SuperoHm chamber at $\pm 4^{\circ} \mathrm{C}$ until use.

\subsection{Preparation of Greek Yogurt}

The Greek yogurt was prepared using UHT skim milk mixed with $2.5 \%(\mathrm{~m} / \mathrm{v})$ powder skim milk, followed by homogenization and heat treatment at $90^{\circ} \mathrm{C}$ for $3 \mathrm{~min}$. Then, it was cooled to $42^{\circ} \mathrm{C}$ and inoculated with $0.2 \%(\mathrm{v} / \mathrm{v})$ dairy culture, followed by light homogenization. After the addition of the culture, the milk was maintained at $42^{\circ} \mathrm{C}$ in a BOD model SuperoHm fermentation chamber until reaching a pH of approximately 5 and an acidity equivalent to $0.70 \%$ lactic acid. After fermentation, the gel was cooled to approximately $8^{\circ} \mathrm{C}$.

Next, the mass was filtered through fabric filters for approximately $24 \mathrm{~h}$ at $4^{\circ} \mathrm{C}$. After filtration, the natural Greek yogurt was mixed with the desired quantities of sucralose, defined by methods for determining the ideal sweetness (Vickers, 2001) and estimating its magnitude (Stone \& Oliver, 1969; Stone \& Sidel, 2004), i.e., 0.0162 
$\mathrm{g} / 100 \mathrm{~g}$ and $0.0182 \mathrm{~g} / 100 \mathrm{~g}$ for the Greek araticum and mangaba yogurts, respectively.

Then, the sweetened Greek yogurt was homogenized and $5 \%(\mathrm{~m} / \mathrm{m}$ ) fruits pulp (araticum and mangaba) were added as a sweetener, as described above. After homogenization, the samples were placed in plastic containers with an average holding capacity of $250 \mathrm{~g}$, identified, and stored at $4^{\circ} \mathrm{C}$ in the BOD fermentation chamber until the time of analysis.

The study design consisted of an analysis of phenolic compounds, instrumental texture, and sensory profiles (QDA), and panelist-acceptance and purchase-intention tests for the araticum- and mangaba-flavored Greek yogurt after 7 or 28 days of storage.

\subsubsection{Follow-up of Fermentation}

Fermentation of the Greek yogurt was monitored by analyzing the $\mathrm{pH}$ using a digital potentiometer (HANNA instruments, model HI 2221, Number 943.71) and the acidity, which was expressed in terms of lactic acid equivalents, as determined by titration (Number 937.05) and performed according to the analytical standards of the Association of Official Analytical Chemists (AOAC, 2012). Fermentation was interrupted when the value $\mathrm{pH}$ reached 4.7 .

\subsubsection{Total Phenolic Compounds}

The extracts were prepared for determining their total phenolic compounds following the method proposed by Rufino et al. (2010). The results were expressed in $\mathrm{mg}$ of gallic acid equivalent (GAE) per $100 \mathrm{~g}$ of yogurt extract, obtained using the equation of the straight line $\left(y=0.0206 x+0.0131, R^{2}=0.9993\right)$ through the analytical curve plotted with gallic acid standards at concentrations of $0,10,20,30,40$, and $50 \mu \mathrm{g} / \mathrm{mL}$.

\subsubsection{Texture Profile Analysis}

The textural properties of the araticum and mangaba Greek yogurt were analyzed using a Texture Analyzer TA-XT plus instrument (Extralab, Brazil). The parameters used for analyzing and interpreting the results were as follows: test speed: $2 \mathrm{~mm} / \mathrm{s}$; distance penetrated by the device in the sample: $5 \mathrm{~mm}$; cylindrical probe diameter: $35 \mathrm{~mm}$ (A/BE 35); contact force: $100 \mathrm{~g}$; contact time: $5 \mathrm{~s}$; sample size: $60 \pm 10 \mathrm{~g}$; and temperature: $9 \pm 2^{\circ} \mathrm{C}$, under the experimental storage conditions. The data were collected using Texture Expert software for Windows, version 1.20 . The roughness, compressibility, adhesiveness, and cohesiveness were analyzed in triplicate.

\subsubsection{QDA Testing}

Once the microbiological quality of the Greek araticum and mangaba yogurts were evaluated, the sensory analysis was performed in individual sensory cabins at the Federal Institute of Education, Science and Technology of Mato Grosso, Cuiabá Campus, Bela Vista, Cuiabá - MT.

Before starting the sensory analysis, the panelists were presented with the Free and Clarified Consent Term FCCT, which identified the study and those who were responsible for performing it, as well as the legal aspects and objectives of the study. Because the study involved human panelists, it was approved by the Ethics Committee of the Graduate Institute of Education and Health SINOP EIRELI (approval number 1254 772).

The 7-day storage period used in this study was considered as the minimum time limit for performing sensory analyses, given that the aromatic characteristics of the fermented products depend on the chemical and biochemical reactions caused by the interaction of their components (Ordóñez, 2005).

\subsubsection{Preselection of the Sensory Panelists}

A paired-comparison test was performed with 30 panelists after presenting them with two samples of Greek yogurt, one sweetened with $10 \%$ sucrose and the other sweetened with $12.5 \%$ sucrose. The objective was to observe whether the panelists could identify differences in sweetness due to the different sucrose concentrations in the samples. A significant difference in sweetness was observed by the panelists between the samples with a $2.5 \%$ difference in sucrose concentration, and 25 panelists were recruited.

A series of seven triangle-difference tests were applied using Wald's sequential analysis (Meilgaard et al.,1999) to select candidates that were most capable of discriminating between the samples. Two plain Greek yogurt samples were sweetened with sucrose concentration differences of $1.25 \%$ or $2.5 \%$, within the sweetness scale used in this study.

The values of $p 0=0.45, p l=0.70, \alpha=0.05$, and $\beta=0.05$ for the risks were used to analyze the discriminatory capability of the panelists. Therefore, candidates with an ability higher than 0.70 were accepted and candidates with ability lower than 0.45 were rejected, with probabilities of 0.05 of accepting an inadequate candidate and rejecting an adequate candidate. 


\subsubsection{Survey of Descriptors}

Araticum- and mangaba-flavored Greek yogurt samples stored for 7 or 28 days were established as reference samples for sensory profile evaluation. Then, the panelists selected through Wald's sequential analysis (Meilgaard, Civille, \& Carr, 1999) were asked to evaluate the samples in pairs, i.e., two samples of each yogurt flavor. Next, they were asked to describe the similarities and differences between the Greek yogurt samples concerning the appearance, aroma, flavor, and texture, according to the Grid Method (Repertory Grid Kelly's Method) (Moskowitz, 1983).

After surveying the descriptors, the sensory panelists met and, through an open discussion, the most appropriate and important descriptors were selected, which best described the sample attributes. Definitions were also established for each descriptor, and the reference materials to be provided during the training sessions for the panelists were selected.

With the selected attributes, the evaluation forms were prepared with 9-centimeter unstructured scales anchored at their ends, on the left by the terms "mild" or "none" and on the right, "strong" or "many."

\subsubsection{Training of the Panelists}

Three training sessions were performed with the panelists, during which the reference samples selected for the study were provided to form sensory memories so that the scores of the panelists would be in the same range on the scale. The forms prepared with the intensity scales for the defined descriptors were also used during the training. The training ended only after the panelists had no difficulties in evaluating the samples.

\subsubsection{Analysis of the Samples}

Definitive evaluation of the yogurt samples was performed under the same conditions used in the training sessions, however, at this point, the panelists could not use the references. The samples were served in disposable plastic cups with a capacity of $50 \mathrm{~mL}$, containing approximately $30 \mathrm{~mL}$ of each sample and coded with three-digit numbers. The sample presentation was monadic, according to the design of complete balanced blocks by Wakeling and Macfie (1995), and was repeated three times in different sessions, with both Greek yogurt flavors. Hence, the panelists recorded the intensity of each attribute on a $9-\mathrm{cm}$ scale.

\subsubsection{Acceptance and Purchase-Intention Tests}

For the acceptance and purchase-intent tests, 120 regularly consumers of yogurt were invited, composed of both genders and formed by students and employees from of Federal Institute of Education, Science and Technology of Mato Grosso, Cuiabá Campus, Bela Vista, Cuiabá - MT, to perform the affective test with all Greek yogurt samples, concerning the attributes of appearance, aroma, flavor, texture, and overall impression. The samples were provided to the panelists at a temperature between 4 and $8{ }^{\circ} \mathrm{C}$ in complete balanced blocks, in a monadic manner, in white plastic cups coded with three-digit numbers. The acceptance test involved the application of forms prepared with a 9-cm unstructured hedonic scale, anchored at the ends by the terms "I disliked it very much" on the left and "I liked it very much" on the right.

For the purchase-intention test, the five-point purchase attitude scale was used, ranging from the terms "I would certainly buy it" to "I would certainly not buy it" (Meilgaard et al., 1999).

The tests were performed in individual sensory cabins, under white light, at comfortable room temperature $\left(20^{\circ} \mathrm{C} \pm 2^{\circ} \mathrm{C}\right)$, in the absence of noise and external odors, with the aid of the evaluation forms and mineral water provided at room temperature. Each product was evaluated under the same conditions on different dates.

\subsubsection{Statistical Analysis}

The ASSISTAT 7.7 beta software was used for statistical analysis of the results (Silva \& Azevedo, 2009). Analysis of variance was performed to identify significant differences between the analyses, with statistical significance defined as $\mathrm{p}<0.05$. A normality test was performed to justify the choice of Tukey's method. In addition, principal component analysis (PCA) was performed with the data obtained by QDA, using SAS University Edition software, version 3.6.

\section{Results ad Discussion}

\subsection{Monitoring the Fermentation Process}

After fermentation, the Greek yogurt samples presented $\mathrm{pH} 4.52$ and an acidity expressed as $0.74 \%$ lactic acid. The Brazilian legislation does not mention the $\mathrm{pH}$ value expected for commercial yogurt products; however, the $\mathrm{pH}$ is used to monitor yogurt production because it is related to the acidity content and microbial development. According to Kirdar and Gun (2002), the pH of Greek yogurt can reach values of approximately 3.7, with no 
negative effect on product acceptance by consumers.

\subsection{Total Phenolic Compounds}

The presence of phenolic compounds in foods attribute characteristics such as a bitter taste, astringency, and aroma (Shahidi \& Naczak, 1995; Melo, Maciel, de Lima, \& do Nascimento, 2008). The content of phenolic compounds in the Greek yogurt samples was altered by the presence of araticum and mangaba pulp $(5 \mathrm{~g} / 100 \mathrm{~g})$ added during production. The average values of total phenolic compounds found in the araticum-flavored Greek yogurt after 7 and 28 days of storage at $4^{\circ} \mathrm{C}$ were 27.37 and $15.61 \mathrm{mg} \mathrm{GAE} / 100 \mathrm{~g}$, respectively. In contrast, the average levels of total phenolic compounds in mangaba-flavored Greek yogurt samples, analyzed in the same period, were 18.54 and $15.25 \mathrm{mg}$ GAE/100g, respectively. The values of total phenolic compounds were consistent with the expected values, given that the concentration of the fruit pulp added to the yogurt was only 5\% and that mangaba pulp contains on average $935 \mathrm{mg}$ GAE/100g (Rufino et al., 2010) and that araticum pulp contains at least $260.5 \mathrm{mg} \mathrm{GAE} / 100 \mathrm{~g}$ (Damiani et al., 2011). Hence, the addition of 5\% araticum or mangaba pulp represents on average 13 and $46.75 \mathrm{mg}$ of GAE/100 g of yogurt, respectively, which are close to the levels found in the yogurts studied.

The available amount of phenolic compounds was reduced as a function of the storage period ( 7 or 28 days of storage at $4^{\circ} \mathrm{C}$ ). The reduction in the levels of phenolic compounds was most likely due to chemical components with antioxidant properties, i.e., unstable compounds that undergo isomerization and oxidation during processing and storage (Rodriguez-Amaya, 1999).

\subsection{Texture-Profile Analysis (TPA)}

Information obtained with the TPA test by analyzing the Greek araticum and mangaba yogurts after 7 or 28 days of storage enabled the evaluation of texture parameters related to consumer acceptance.

The adhesiveness parameter, defined as the force required to overcome the attractive forces between the food surface and other interactions present in the food, presented negative results for both products: -0.60 and -0.65 kgf.mm for Greek araticum yogurt after 7 and 28 days of storage, respectively, and -0.98 and $-1.03 \mathrm{kgf.mm}$ for Greek mangaba yogurt under the same conditions. This condition represents the force necessary to completely remove a probe from the sample, such that the greater the occupation of the negative area, the more negative is the value obtained in the analysis and, consequently, the greater the adhesiveness. Applying this interpretation to the sensory definition, the value represents the force that must be exerted by the tongue to remove the product adhered to the mouth (Ramos \& Gomide, 2007). Negative adhesiveness results similar to those obtained in this study were found by Mantovani et al. (2012), who reported a value of -0.26 N.s for guava-flavored yogurt after the addition of $5 \%$ powdered milk.

Similar behavior was observed for the cohesiveness parameter, where the Greek araticum yogurt stored for 7 or 28 days had values of -0.42 and $-0.47 \mathrm{kgf}$.mm, and the Greek mangaba yogurt showed values of -0.56 and 0.61 , respectively, under the same storage conditions. Overall, the results indicated that all the analyzed texture parameters demonstrated stable results during the storage period, a desirable condition since it confirms that the product retains similar qualities after four weeks of storage compared to the newly manufactured product, which favors the maintenance of the physicochemical and therefore, the sensory characteristics.

Very few studies have been published regarding the texture parameters of Greek yogurt; however, some authors have provided some information to support new studies. One example is the study by Ramos et al. (2009), who evaluated the texture of Greek yogurt with different formulations by varying the cream contents (with and without its addition) and obtained values ranging from 1.0 to $1.5 \mathrm{kgf} . \mathrm{mm}$ for the roughness parameter, corroborating the study by Ramos et al. (2009). Vidigal et al. (2012) studied the effect of whey protein concentrate on the instrumental texture of fat-free dairy desserts, obtaining roughness values ranging from 1.18 to $1.48 \mathrm{~N}$ for the different formulations. These findings corroborate the data obtained in the present study, considering the similarity of the values obtained for the Greek araticum and mangaba yogurts $(1.33$ and 1,42 kgf.mm, respectively), after 28 days of storage. Most likely, these values are associated with the higher protein content of Greek yogurt, given that the higher the protein density of the matrix, the greater its resistance to deformation.

\subsection{QDA Testing}

\subsubsection{Preselection and Training of the Sensory Panelists}

Using the values of $p 0=0.45, p l=0.70, \alpha=0.05$, and $\beta=0.05$, straight lines for $d 0$ and $d l$ were plotted, and the performance of the candidates in the triangle tests was evaluated in relation to these lines. With the triangle tests and sequential analysis, 12 panelists were preselected. 
After defining the attributes and determining the scales, the preselected sensory panelists participated in 3 training sessions, and each panelist was trained for the whole set of attributes. At the end of the training, the preselected trainers were evaluated in regard to their repeatability, ability to discriminate between samples, and consensus with the sensory panelists, using the form prepared for the QDA.

\subsubsection{Survey of Descriptors}

Using the list obtained with the Grid Method or "Kelly's Repertory Grid Method," the sensory panelists of panelists formed a consensus and selected 15 attributes for the araticum and mangaba-flavored Greek yogurts, including five attributes related to appearance (brownish-white color [araticum flavor], greenish-white color [mangaba flavor], lightness, apparent viscosity, and the presence of particles), seven attributes related to aroma (astringency, sweet taste, bitter taste, acid taste, araticum flavor and mangaba flavor, and yogurt flavor), and three attributes related to texture (presence of particles, creaminess, and fullness), as shown in Table 1.

Table 1. Descriptors for araticum- and mangaba-flavored Greek yogurts, with definitions and references

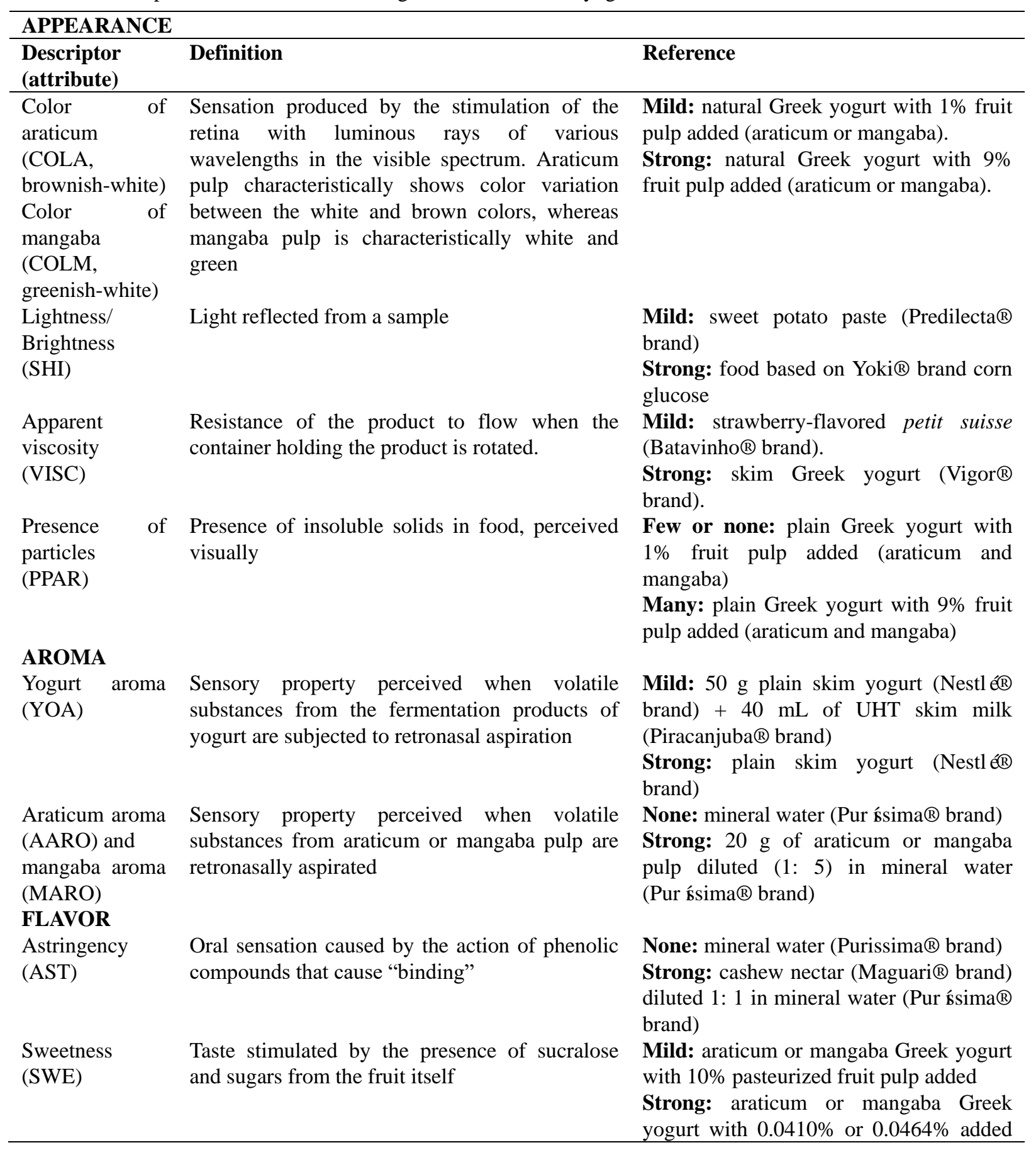


sucralose, respectively

Bitterness (BIT) Bitter taste perceived after the ingestion of a None: mineral water (Purissima ${ }^{\circledR}$ brand) food

Mild: one Cold and Flu Relief (Anador ${ }^{\circledR}$ brand) tablet dissolved in $500 \mathrm{ml}$ mineral water

Acidity (ACID) Characteristic acid taste of lactic and citric acid fermentation

Mild: araticum or mangaba Greek yogurt with no added sucrose, diluted 1: 1 in UHT skim milk

Strong: araticum or mangaba Greek yogurt with no added sucrose $\begin{array}{ll}\text { Araticum flavor } & \text { Characteristic flavor of natural araticum and } \\ \text { (AFLA) } & \text { mangaba pulp }\end{array}$ None: mineral water (Purissima ${ }^{\circledR}$ brand) Strong: $20 \mathrm{~g}$ of araticum or mangaba pulp diluted 1: 5 in mineral water Mangaba flavor (MFLA)

Yogurt flavor Characteristic flavor of yogurt (fermented milk) (Purissima ${ }^{\circledR}$ brand)

(YOF)

Mild: $50 \mathrm{~g}$ plain skim yogurt (Nestlé ${ }^{\circledR}$ brand) $+40 \mathrm{~mL}$ UHT skim milk (Piracanjuba ${ }^{\circledR}$ brand)

Strong: Plain skim yogurt (Nestlé ${ }^{\circledR}$ brand)

\section{TEXTURE}

Presence of Presence of perceptible lumps or particles in particles yogurt during the tasting

Few or none: plain Greek yogurt with $1 \%$ araticum or mangaba pulp added

(PART)

Many: plain Greek yogurt added with 9\% araticum or mangaba pulp added

Creaminess The property of resistance to flow of a product (CREAM) in the oral cavity

Mild: strawberry-flavored dairy beverage (Itambé® brand)

Strong: strawberry-flavored petit suisse (Batavinho ${ }^{\circledR}$ brand)

Fullness Sensation of fullness in the oral cavity Mild: strawberry-flavored dairy beverage (Itambé® brand)

Strong: strawberry-flavored petit suisse (Batavinho ${ }^{\circ}$ brand)

These attributes related to the descriptors and definitions for the reference araticum- and mangaba-flavored Greek yogurt samples. After selecting the attributes, the evaluation forms were prepared to track the sensory profiles of the samples.

\subsubsection{Evaluation of the Samples}

Once the composition of the sensory panelist of 12 trained judges for the QDA was defined, the tests were performed three times to evaluate the attributes of the samples of Greek araticum and mangaba yogurt after 7 days or 28 days of storage. The sensory profiles of the Greek yogurt samples obtained with the QDA are represented graphically (Figures 1 ).

Table 2 indicates that both Greek yogurts showed significant differences at the 5\% probability level, after 7 or 28 days in storage, in terms of the lightness, viscosity, presence of particles, araticum aroma, bitterness, araticum flavor, and fullness for the Greek araticum yogurt. Significant differences in the lightness, yogurt aroma, and presence of particles were also found for the Greek mangaba yogurt, between both storage durations. 
Table 2. Mean values obtained for each sensory attribute in the analysis of the samples by the trained panelists for Greek araticum and mangaba yogurt

\begin{tabular}{|c|c|c|c|c|c|c|c|c|}
\hline \multicolumn{5}{|c|}{ Greek araticum yogurt } & \multicolumn{4}{|c|}{ Greek mangaba yogurt } \\
\hline \multirow[t]{2}{*}{ Attributes } & \multicolumn{5}{|l|}{ Days } & \multicolumn{3}{|c|}{ Days } \\
\hline & & 7 & 28 & $\mathrm{msd}^{*}$ & & 7 & 28 & $\mathrm{msd}^{*}$ \\
\hline \multirow[t]{4}{*}{ Appearance } & COLA & $2.73^{\mathrm{a}}$ & $2.94^{\mathrm{a}}$ & 0.46 & COLM & $2.96^{\mathrm{a}}$ & $2.94^{\mathrm{a}}$ & 0.38 \\
\hline & SHI & $3.54^{\mathrm{b}}$ & $5.14^{\mathrm{a}}$ & 0.46 & SHI & $3.42^{\mathrm{b}}$ & $3.85^{\mathrm{a}}$ & 0.40 \\
\hline & VISC & $7.59^{\mathrm{a}}$ & $6.88^{\mathrm{b}}$ & 0.26 & VISC & $6.59^{\mathrm{a}}$ & $6.27^{\mathrm{a}}$ & 0.34 \\
\hline & PPAR & $1.60^{\mathrm{b}}$ & $3.55^{\mathrm{a}}$ & 0.26 & PPAR & $1.79^{\mathrm{a}}$ & $1.67^{\mathrm{a}}$ & 0.30 \\
\hline \multirow{2}{*}{ Aroma } & YOA & $3.17^{\mathrm{a}}$ & $3.12^{\mathrm{a}}$ & 0.54 & YOA & $4.89^{\mathrm{a}}$ & $4.50^{\mathrm{b}}$ & 0.32 \\
\hline & AARO & $3.71^{\mathrm{b}}$ & $4.62^{\mathrm{a}}$ & 0.55 & MARO & $3.83^{\mathrm{a}}$ & $3.87^{\mathrm{a}}$ & 0.46 \\
\hline \multirow{6}{*}{ Flavor } & AST & $0.84^{\mathrm{a}}$ & $0.88^{\mathrm{a}}$ & 0.20 & AST & $2.15^{\mathrm{a}}$ & $1.93^{\mathrm{a}}$ & 0.29 \\
\hline & SWE & $4.41^{\mathrm{a}}$ & $4.61^{a}$ & 0.40 & SWE & $4.49^{\mathrm{a}}$ & $4.61^{\mathrm{a}}$ & 0.54 \\
\hline & BIT & $0.41^{\mathrm{b}}$ & $0.59^{\mathrm{a}}$ & 0.14 & BIT & $0.98^{\mathrm{a}}$ & $1.02^{\mathrm{a}}$ & 0.35 \\
\hline & ACID & $3.43^{\mathrm{a}}$ & $3.52^{\mathrm{a}}$ & 0.44 & ACID & $3.92^{\mathrm{a}}$ & $4.11^{\mathrm{a}}$ & 0.58 \\
\hline & AFLA & $4.34^{\mathrm{b}}$ & $5.36^{\mathrm{a}}$ & 0.49 & MFLA & $5.05^{\mathrm{a}}$ & $5.39^{\mathrm{a}}$ & 0.51 \\
\hline & YOF & $3.82^{\mathrm{a}}$ & $4.22^{\mathrm{a}}$ & 0.46 & YOF & $4.34^{\mathrm{a}}$ & $4.38^{\mathrm{a}}$ & 0.47 \\
\hline \multirow[t]{3}{*}{ Texture } & PART & $1.76^{\mathrm{a}}$ & $1.79^{\mathrm{a}}$ & 0.31 & PART & $1.50^{\mathrm{a}}$ & $1.18^{\mathrm{b}}$ & 0.19 \\
\hline & CREAM & $6.80^{\mathrm{a}}$ & $6.45^{\mathrm{a}}$ & 0.39 & CREAM & $6.07^{\mathrm{a}}$ & $5.70^{\mathrm{a}}$ & 0.43 \\
\hline & FULL & $7.09^{\mathrm{a}}$ & $6.46^{\mathrm{b}}$ & 0.36 & FULL & $6.40^{\mathrm{a}}$ & $6.19^{\mathrm{a}}$ & 0.26 \\
\hline
\end{tabular}

* Minimum significant difference at the error level of 5\% (Tukey's Test). For each attribute, mean values followed by different letters in the same row represent statistical differences at the 5\% level. Abbreviation: COLA: color of araticum (brownish-white); COLM: color of mangaba (greenish-white); SHI: lightness; VISC: apparent viscosity; PPAR: presence of particles; YOA: yogurt aroma; AARO: araticum aroma; MARO: mangaba aroma; AST: astringency; SWE: sweetness; BIT: bitterness; ACID: acidity; AFLA: araticum flavor; MFLA: mangaba flavor; YOF: yogurt flavor; PART: particles; CREAM: creaminess; FULL: fullness

The attributes of fullness, creaminess, and viscosity showed scores ranging from 6.45 to 7.59 points in the $9-\mathrm{cm}$ scale for the Greek araticum yogurt (Figure 1A) and from 5.70 to 6.59 for the Greek mangaba yogurt (Figure 1B), indicating the strong intensity of these attributes perceived by the panelists. The evaluation of these attributes obtained by sensory analysis correlated with that obtained when analyzing the instrumental texture.

The creaminess and viscosity (defined in this study as properties that indicate the resistance to flow of a product in the oral cavity and as the resistance of the product to flow when the recipient is rotated with the product, respectively) were associated with the industrial adhesiveness (which represents the force required to remove the probe from the sample), resulting in negative values when the readings were taken. Atamian, Olabi, Kebbe-Baghdadi, and Toufeili (2014) characterized the physicochemical and sensory properties of Greek yogurt (Labneh) containing whole fat, reduced fat, and low fat from cows, goats, and sheep, concluding that the sensory viscosity and instrumental adhesive force values were correlated, obtaining negative values, similar to the results of this study.

Lightness is another attribute that is commonly evaluated for yogurt products and is related to the amount of reflected from the surface of luminous objects. Based on this definition, Ramos and Gomide (2007) explained that shiny surfaces appear to have darker and more intense colors, while less shiny surfaces and those with texture appear to be lighter and to have less intense colors, which demonstrates a practical application of the reflection phenomenon. In accordance with this principle, the sensory profile results indicated that the Greek araticum yogurt samples were perceived to have significantly greater lightness $(\mathrm{p}<0.05)$ when stored for 7 days than after being stored for 28 days, as well as the highest perceived color intensity. In agreement, the Greek mangaba yogurt was perceived to be less shiny and to have a less intense color.

Color is one of the main sensory attributes of food quality. In yogurts produced with araticum and mangaba pulps, color is provided by the presence of phenolic compounds. The levels of phenolic compounds decreased from $27.37 \mathrm{mg} / 100 \mathrm{~g}$ of gallic acid (7 days) to $15.61 \mathrm{mg} / 100 \mathrm{~g}$ of gallic acid (28 days) in the araticum-flavored yogurt. Similarly, the phenolic compound levels decreased from $18.54 \mathrm{mg} / 100 \mathrm{~g}$ of gallic acid (7 days) to 15.25 $\mathrm{mg} / 100 \mathrm{~g}$ of gallic acid (28 days) with the mangaba-flavored yogurt, which was not a large enough reduction to impact the perception of the color intensity in the sensory profile.

In turn, the concentration of phenolic compounds was significantly higher $(p<0.05)$ in the Greek araticum 
yogurts than in the Greek mangaba yogurt, which correlated with differences in the attributes of araticum aroma, araticum flavor, and bitterness.

The Greek mangaba yogurt presented a significant yogurt aroma, which was most likely influenced by the acidity levels due to the mangaba pulp. According to Campos, Knoch, Hiane, Ramos, and Ramos Filho (2011), the titratable acidity values in recently gathered fruits are, on average, $0.55 \mathrm{~g}$ of citric acid per $100 \mathrm{~g}$ of fruit, which changes to $0.76 \mathrm{~g}$ of citric acid depending on the conservation method. Damiani et al. (2011) analyzed the acidity content of araticum pulp in terms of different organic acids and verified that malic acid, with the content of $0.096 \mathrm{~g}$ per $100 \mathrm{~g}$ of fruit, was the most abundant acid in the pulp. When developing Greek yogurt with a sweet taste and other sensory characteristics similar to traditional yogurt, several factors must be considered in order to avoid the occurrence of undesirable sensory characteristics for the consumer, such as a persistently sweet taste or the presence of a bitter taste, among others (Lim, 1989; Portmann \& Kilcast, 1998).

The sensory-profile results for the araticum and mangaba yogurts indicated the perceptions of the evaluators when faced with a stable product and that adding the sweetener sucralose to the yogurt did not promote negative characteristics associated with the storage conditions. The graphic view of the mean values of each descriptor (Figure 1) demonstrates similarities in the sensory profiles for the araticum- and mangaba-flavored Greek yogurt samples stored for 7 or 28 days.

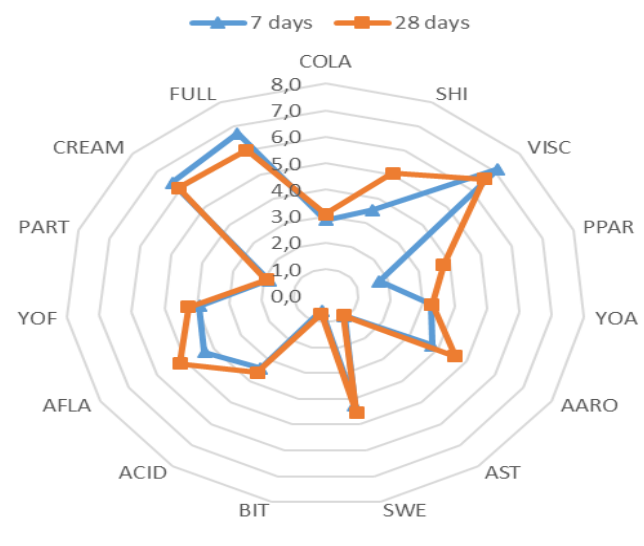

Araticum (A)

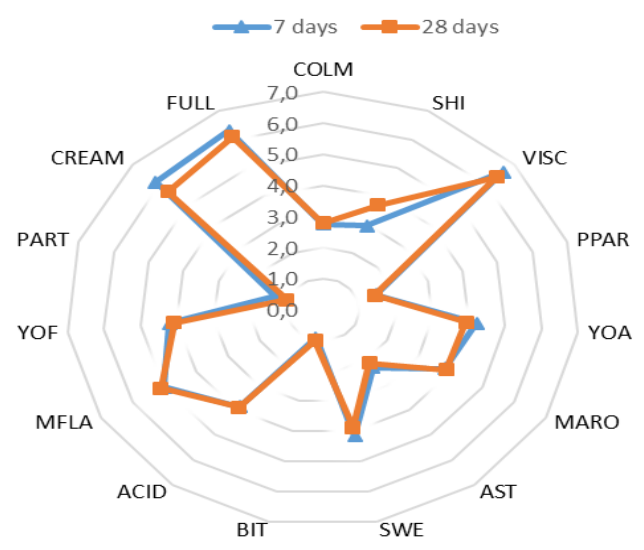

Mangaba (B)

Figure 1. Sensory profile of Greek araticum (A) and mangaba yogurt samples (B) after storage for 7 or 28 days

COLA: color of araticum (brownish-white); COLM: color of mangaba (greenish-white); SHI: lightness; VISC: apparent viscosity; PPAR: presence of particles; YOA: yogurt aroma; AARO: araticum aroma; MARO: mangaba aroma; AST: astringency; SWE: sweetness; BIT: bitterness; ACID: acidity; AFLA: araticum flavor; MFLA: mangaba flavor; YOF: yogurt flavor; PART: particles; CREAM: creaminess; FULL: fullness

PCA was performed using the data collected for each sample and panelist. Components I and II combined represented $81.23 \%$ of the variability between the Greek araticum yogurts (Figure 2) and $70.83 \%$ of the variability between the Greek mangaba yogurts (Figure 3), tested after 7 and 28 days of storage. 


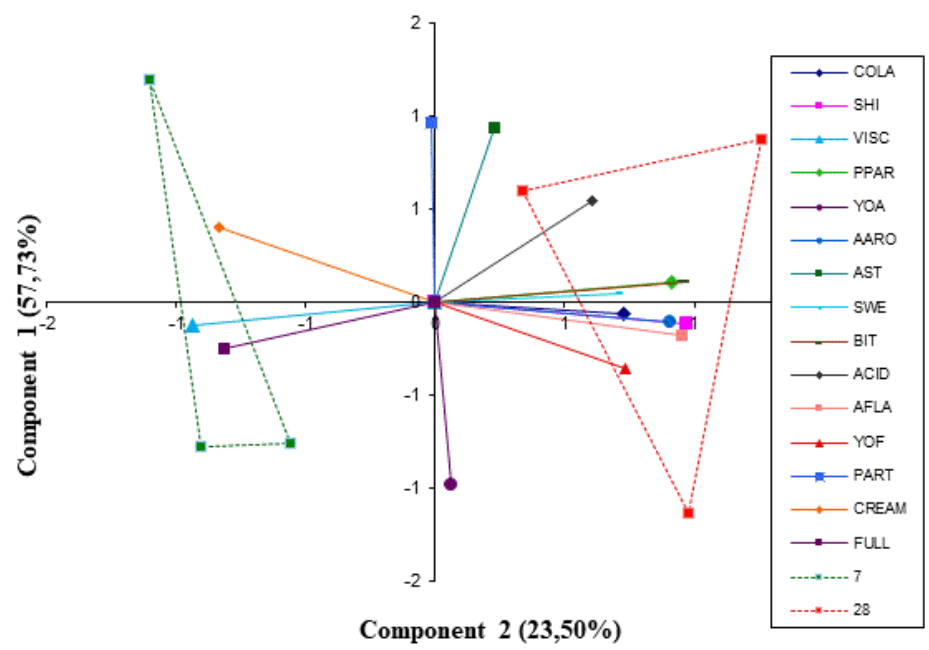

Figure 2. Two-dimensional representation of the principal component analysis of the Greek araticum yogurt samples

Abbreviations: COLA: color of araticum (brownish-white); SHI: lightness; VISC: apparent viscosity; PPAR: presence of particles; YOA: yogurt aroma; AARO: araticum aroma; AST: astringency; SWE: sweetness; BIT: bitterness; ACID: acidity; AFLA: araticum flavor; YOF: yogurt flavor; PART: particles; CREAM: creaminess; FULL: fullness; 7 and 28 days of storage

The vectors farthest from zero represented the most important descriptors for characterizing the samples. As such, the araticum-flavored Greek yogurt stored for 7 days was best characterized by the attributes of viscosity and fullness, while the most prominent attributes were the lightness, araticum aroma, and araticum flavor after the samples were stored for 28 days.

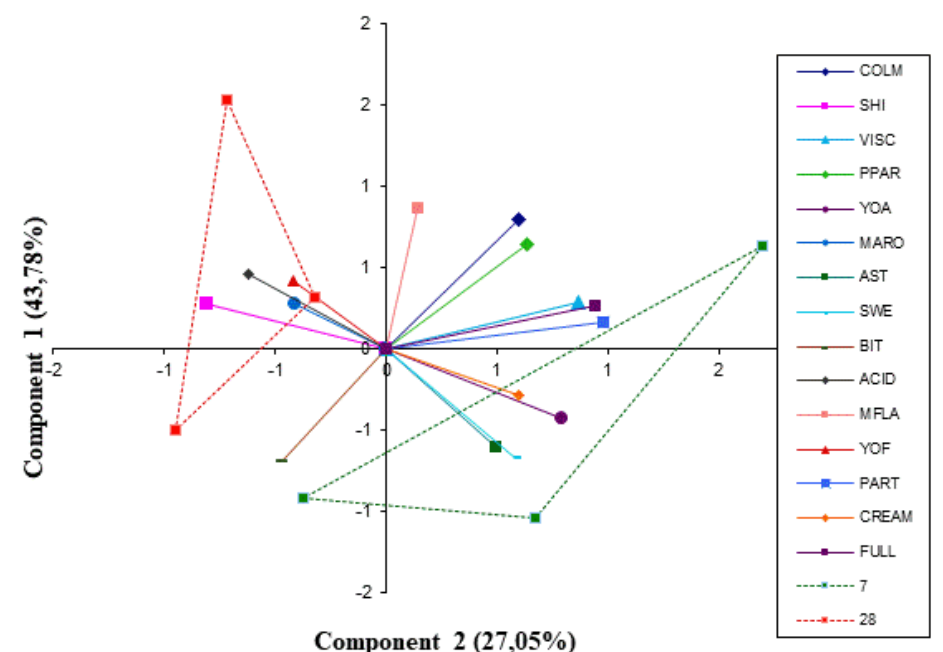

Figure 3. Two-dimensional representation of the principal component analysis of the Greek mangaba yogurt samples

COLM: color of mangaba (greenish-white); SHI: lightness; VISC: apparent viscosity; PPAR: presence of particles; YOA: yogurt aroma; MARO: mangaba aroma; AST: astringency; SWE: sweet; BIT: bitter; ACID: acidity; MFLA: mangaba flavor; YOF: yogurt flavor; PART: particles; CREAM: creaminess; FULL: fullness; 7 and 28 days of storage

The mangaba-flavored Greek yogurt was best characterized by the presence of particles and the yogurt aroma after 7 days of storage, while the samples stored for 28 days were best characterized by the presence of lightness. 


\subsubsection{Acceptance and Purchase-Intention Test}

The acceptance test results indicated significant differences for the appearance and texture attributes $(\mathrm{p}<0.05)$ and for the aroma and flavor attributes $(\mathrm{p}<0.01)$ between the samples of araticum Greek yogurt stored for 7 or 28 days at $4^{\circ} \mathrm{C}$. In contrast, the acceptance test results for the Greek mangaba yogurt showed no significant differences in any of the evaluated attributes after storage for 7 or 28 days.

Both the Greek araticum and mangaba yogurt samples presented mean scores from 6.29 to 7.36 , which is equivalent to the hedonic terms of "I liked it slightly" and "I liked it moderately," indicating their good levels of acceptance. These results are similar to those found by Oliveira et al. (2008), who developed a formulation of araticum yogurt and studied the sensory acceptance, although 15\% sugar and 0 to $25 \%$ araticum pulp was added. Reis et al. (2009) studied the impact of the use of different sweeteners on the acceptance of strawberry-flavored yogurt by applying different analysis techniques on the results of acceptance.

They concluded that of all sweeteners tested, the yogurt produced with sucralose showed the greatest acceptance, with no significant difference between the samples produced with sucrose. These facts demonstrate the viability of developing formulations with lower fat contents, lower concentrations of pulp, and of substituting sugar with sucralose, as in the present study.

Regarding the intent to purchase the products evaluated, $80 \%$ would buy the araticum Greek yogurt and $85 \%$ would buy the mangaba Greek yogurt after 7 days of storage at $4^{\circ} \mathrm{C}$. In contrast, $71 \%$ would buy the araticum Greek yogurt and $77 \%$ would buy the mangaba Greek yogurt after 28 days of storage at $4^{\circ} \mathrm{C}$.

\section{Conclusion}

The sensory profile and acceptance test results of the Greek araticum and mangaba yogurts indicated the preparation of products with well-balanced sensory characteristics, with no development of negative perceptions caused by adding sucralose to the yogurt after storage for different times. The highest concentration of phenolic compounds in the araticum Greek yogurt was perceived by the panelists in relation to the aroma and flavor attributes. Substituting sucrose with sucralose was not imperceptible under the storage and consumption conditions. During the storage period, the araticum-flavored Greek yogurt was best characterized by the attributes of viscosity, fullness, aroma, and araticum flavor, whereas the mangaba-flavored Greek yogurt was best characterized by the aroma, lightness, and presence of particles. The yogurts remained adequate for consumption after 28 days of storage, which is important given that yogurt is a product with no chemical preservatives added.

\section{Acknowledgments}

This study was supported by National Council for Scientific and Technological Development [public notice 17, process no. 467554/2014-5] and the Federal Institute of Education, Science and Technology of Mato Grosso, Brazil, Cuiabá Campus, Bela Vista.

\section{References}

AOAC. (2012). Association of official analytical chemists. Official methods of analysis - AOAC International. (19th ed.). Maryland, The United States of America (USA).

Atamian, S., Olabi, A., Kebbe-Baghdadi, O., \& Toufeili, I. (2014). The characterization of the physicochemical and sensory properties of full-fat, reduced-fat and low-fat bovine, caprine, and ovine Greek yogurt (Labneh). Food Science \& Nutrition, 2, 164-173. https://doi.org/10.1002/fsn3.89

Cardoso, J. M. P., \& Bolini, H. M. A. (2007). Different sweeteners in peach nectar: ideal and equivalent sweetness. Food Research International, 40, 1249-1253. https://doi.org/10.1016/j.foodres.2007.08.004

Campos, R. P., Knoch, B., Hiane, P. A., Ramos, M. I. L., \& Ramos Filho, M. M. (2011). MCP em mangabas armazenadas em temperatura ambiente e a $11{ }^{\circ} \mathrm{C}$. Revista Brasileira de Fruticultura, 33, 206-212. http://dx.doi.org/10.1590/S0100-29452011000500024

Carbonell-Barrachina, A. A. (2019). Sensory Evaluation of Food - A New Trend for Assessing Food Quality. Advanced Research in Life Sciences, 3(1), 1-2. https://doi.org/10.2478/arls-2019-0001

De Souza, V. R., Pereira, P. A. P., Pinheiro, A. C. M., Bolini, H. M. A., Borges, S. V., \& Queiroz, F. (2013). Analysis of various sweeteners in low-sugar mixed fruit jam: Equivalent sweetness, time intensity analysis and acceptance test. International Journal of Food Science \& Technology, 48, 1541-1548. https://doi.org/10.1111/ijfs.12123

Damiani, C., Vilas-Boas, E. V. de B., Asquieri, E. R., Lage, M. E., de Oliveira R. A., da Silva, F. A., Pinto, D. M., 
Rodrigues, L. J., da Silva, E. P., \& de Paula, N. R. F. (2011). Characterization of fruits from the savanna: Araça (Psidium guinnensis Sw.) and Marolo (Annona crassiflora Mart.). Ciência e Tecnologia de Alimentos 31, 723-729. http://dx.doi.org/10.1590/S0101-20612011000300026

Dutcosky, S. D. (2013). Análise Sensorial de Alimentos. (4th ed.). rev. e ampl. Curitiba: Champagnat. 540 p.

Esmerino, E. A., Cruz, A. G. E., Pereira, P. R., Rodrigues, J. B., Faria, J. A. F., \& Bolini, H. M. A. (2013). The influence of sweeteners in probiotic Petit Suisse cheese in concentrations equivalent to that of sucrose. Journal Dairy Science, 96, 5512-5521. https://doi.org/10.3168/jds.2013-6616

Goldsmith, L. A., \& Merkel, C. M. (2001). Sucralose. In L. B. Nabors (Ed.), Alternative Sweeteners. (pp. 185-208). New York: Marcel Dekker, Inc.

Jaoude, D. A., Olabi, A., Najm, N. E. O., Malek, A., Saadeh, C. Baydoun, E., \& Toufeili, I. (2010). Chemical composition, mineral content and cholesterol levels of some regular and reduced-fat white brined cheeses and strained yogurt (Labneh). Dairy Science Technology, 90, 699-706. https://doi.org/10.1051/dst/2010026

Jørgensen, C. E., Abrahamsen, R. K., Rukke, E-O., Hoffmann, T. K., Johansen, A-G. \& Skeie, S. B. (2019). Processing of high-protein yoghurt - A review. International Dairy Journal, 88, 42-59. https://doi.org/10.1016/j.idairyj.2018.08.002

Kirdar, S., \& Gun, I. (2002). Microbiological, chemical and physical properties of strained yoghurt consumed in Burdur market. Gida, 27, 59-64.

Lim, H., Setser, C. S., \& Kim, S. S. (1989). Sensory studies of high potency multiple sweetener systems for shortbread cookies with and without polydextrose. Journal of Food Science, 54, 625-629. https://doi.org/10.1111/j.1365-2621.1989.tb04667.x

Mantovani, D., Corazza, M. L., Filho, L. C., \& Da Costa, S. C. (2012). Elaboração de iogurte com diferentes concentrações de sólidos totais, análise físico-química e perfil da textura. Revista Brasileira de Tecnologia Agroindustrial, 06, 680-687. https://doi.org/10.3895/S1981-36862012000100007

Meilgaard, M., Civille, G. V., \& Carr, B. T. (1999). Sensory evaluation techniques. (3rd ed.). New York: CRC Press. https://doi.org/10.1201/9781439832271

Melo, E. A., Maciel, M. I. S., de Lima, V. L. A. G., \& do Nascimento, R. J. (2008). Capacidade antioxiante de frutas. Revista Brasileira de Ciências Farmacêuticas, 44, 193-201. https://doi.org/10.1590/S1516-93322008000200005

Moraes, P. C. B. T., \& Bolini, H. M. A. (2010). Different sweeteners in beverages prepared with instant and roasted ground coffee: ideal and equivalent sweetness. Journal of Sensory Studies, 25, 1-11. https://doi.org/10.1111/j.1745-459X.2010.00275.x

Morais, E. C., Morais, A. R., Cruz, A. G., \& Bolini, H. M. A. (2014). Development of chocolate dairy dessert with addition of prebiotics and replacement of sucrose with different high-intensity sweeteners. Journal of Dairy Science, 97, 1-10. https://doi.org/10.3168/jds.2013-7603

Morais, E. C., Patias, S. G. O., Ferreira, N. S. S., Picanço, N. F. M., Rodrigues, E. C., Nascimento, E., \& Faria, R. A. P. G. (2017). Compostos bioativos e características físico-químicas de polpa de araticum in natura e pasteurizada. Brazilian Journal of Food Technology, 20, e2016142. http://dx.doi.org/10.1590/1981-6723.14216

Moskowitz, H. R. (1983). Product testing and sensory evaluation of foods. Westport: Food and Nutrition Press.

Nsabimana, C., Jiang, B., \& Kossah, R. (2005). Manufacturing, properties and shelf life of Labneh: a review. International Journal of Dairy Technology, 58, 129-137. https://doi.org/10.1111/j.1471-0307.2005.00205.x

Oliveira, K. A. M., Ribeiro, L. S., de Oliveira, G. V., Pereira, J. M. A. T. K., Mendonça, R. C. S., \& Assumpção, C. F. (2008). Desenvolvimento de formulação de iogurte de araticum e estudo da aceitação sensorial. Alimentos e Nutrição, 19, 277-281. Retrieved from https://www.researchgate.net/profile/Regina_Mendonca/publication/49599932_DESENVOLVIMENTO_D E_FORMULACAO_DE_IOGURTE_DE_ARATICUM_E_ESTUDO_DA_ACEITACAO_SENSORIAL/li nks/00463537397786e650000000/DESENVOLVIMENTO-DE-FORMULACAO-DE-IOGURTE-DE-ARA TICUM-E-ESTUDO-DA-ACEITACAO-SENSORIAL.pdf

Ordóñez, J. A. P. (2005). Tecnologia de alimentos: alimentos de origem animal. vol. 2. Porto Alegre: Artmed.

Portmann, M. O., \& Kilcast, D. (1998). Descriptive profiles of synergistic mixtures of bulk and intense 
sweeteners. Food Quality Preference, 9, 221-229. https://doi.org/10.1016/S0950-3293(97)00071-2

Ramos, E. M., \& Gomide, L. A. M. (2007). Avaliação da qualidade de carnes: fundamentos e metodologias. (1st ed.). Viçosa - Minas Gerais: Ed. UFV.

Ramos, T. M., Gajo, A. A., Pinto, S. M., Abreu, L. R., \& Pinheiro, A. C. (2009). Perfil de textura de Labneh (iogurte grego). Revista do Instituto de Laticínios Cândido Tostes, 64, 8-12. Retrieved from https://www.revistadoilct.com.br/rilct/article/view/85/90

Reis, R. C., Minim, V. P. R., Dias, B. R. P., Chaves, J. B. P., \& Minim, L. A. (2009). Impacto da utilização de diferentes edulcorantes na aceitabilidade de iogurte "light" sabor morango. Alimentos e Nutrição, 20, 53-60.

Rodriguez-Amaya, D. B. A (1999). Guide to carotenoid analysis in foods. Washington DC: International Life Sciences Institute (ILSI) Press. Retrieved from https://www.researchgate.net/profile/Mark_Bruno/post/What_wavelength_should_I_use_to_quantify_carot enoids/attachment/59d63352c49f478072ea21b8/AS:273642296938498@1442252815121/download/carote noid+Analysis+Guide.pdf

Rodrigues, J. B., Paixão, J. A., Cruz, A. G., \& Bolini, H. M. A. (2015). Chocolate milk with chia oil: ideal sweetness, sweeteners equivalence, and dynamic sensory evaluation using a time-intensity methodology. Journal of Food Science, 80, 2944-2949. https://doi.org/10.1111/1750-3841.13120

Rufino, M. S. M., Alves, R. E., de Brito, E. S., Pérez-Jiménez, J., Saura-Calixto, F., \& Mancini-Filho, J. (2010). Bioactive compounds and antioxidant capacities of 18 non-traditional tropical fruits from Brazil. Food Chemistry, 121, 996-1002. https://doi.org/10.1016/j.foodchem.2010.01.037

SAS (Statistical Analysis System) University Edition 3.6.

Silva, F. A. S., \& Azevedo, C. A. V. (2009). Principal Component analysis in the software Assistat-Statistical Attendance. World Congress On Computers In Agriculture, 7.

Souza, V. R., Pinheiro, A. C. M., Carneiro, J. D. S., Pinto, S. M., Abreu, L. R., \& Menezes, C. C. (2011). Analysis of various sweeteners in petit suisse cheese: Determination of the ideal and equivalent sweetness. Journal of Sensory Studies, 26, 339-345. https://doi.org/10.1111/j.1745-459X.2011.00349.x

Stone, H., \& Oliver, S. M. (1969). Measurement of the relative sweetness of selected sweeteners and sweetener mixtures. Journal of Food Science, 34, 215-222. https://doi.org/10.1111/j.1365-2621.1969.tb00922.x

Stone, H., \& Sidel, J. L. (2004). (3rd ed.). Sensory evaluation practice. New York: Elsevier Academic Press.

Shahidi, F., \& Naczk, M. (1995). Food Phenolics: sources, chemistry, effects and applications, Lancaster: Technomic Pub. Co.

Tamime, A. Y., \& Robinson, R. K. (2007). Yoghurt: science and technology. (3rd Ed.). Cambridge, Woodhead Publishing Limited.

Vickers, Z., Holton, E., \& Wang, J. (2001). Effect of ideal-relative sweetness on yogurt consumption. Food Quality and Preference, 12, 521-526. https://doi.org/10.1016/S0950-3293(01)00047-7

Vidigal, M. C. T., Minim, V. P. R., Ramos, A. M., Ceresino, E. B., Diniz, M. D. M. S., Camilloto, G. P., \& Minim, L. A. (2012). Effect of whey protein concentrate on texture of fat-free desserts: sensory and instrumental measurements. Ciência e Tecnologia de Alimentos, 32, 412-418. http://dx.doi.org/10.1590/S0101-20612012005000047

Wakeling, I. N., \& Macfie, J. H. (1995). Designing consumer trials balanced for first and higher orders of carry-over effect when only a subset of $\kappa$ samples from $\tau$ may be tested. Food Quality and Preference, 6 , 299-308. https://doi.org/10.1016/0950-3293(95)00032-1

\section{Copyrights}

Copyright for this article is retained by the author(s), with first publication rights granted to the journal.

This is an open-access article distributed under the terms and conditions of the Creative Commons Attribution license (http://creativecommons.org/licenses/by/4.0/). 